\title{
Concordance between appendicular skeletal muscle mass measured with DXA and estimated with mathematical models in middle-aged women
}

Nirmala Rathnayake ${ }^{1 *}$, Gayani Alwis ${ }^{2}$, Janaka Lenora ${ }^{3}$ and Sarath Lekamwasam ${ }^{4}$

\begin{abstract}
Background: Appendicular skeletal muscle mass (ASMM) is a measure of body muscle content, and it correlates with nutrition and physical status. Estimation of ASMM using anthropometric models is a well-established strategy to overcome issues related to the restricted availability of sophisticated techniques in measuring ASMM. This study aimed to assess the validity of four selected anthropometric models in estimating ASMM in middle-aged women in Sri Lanka.

Methods: A group of women $(n=165)$ aged 30-60 years underwent a series of anthropometric measurements such as body weight, height, circumferences, and skin fold thickness at specific sites. The limb circumferences were corrected for subcutaneous adipose tissue thickness. Two models developed by Lee et al. (ASM 1, ASM2) and two models developed by Wen et al. (ASM3, ASM4) were validated using ASMM measured by dual energy $x$-ray absorptiometry $\left(A_{S M M} M_{D A}\right)$ as the reference standard.

Results: Mean (SD) age of the study group was 49.0 (8.2) years. Mean (SD) ASMM DXA and ASMM estimated by the four models were $A S M M_{D X A}=15.39(2.75) \mathrm{kg}, \mathrm{ASM} 1=18.36(3.27) \mathrm{kg}, \mathrm{ASM} 2=16.46(3.01) \mathrm{kg}, \mathrm{ASM} 3=15.44(2.40) \mathrm{kg}$, and ASM4 $=14.44(2.45) \mathrm{kg}$. Correlations of ASMM DXA with ASMM estimated by the models were as follows: ASM1, $r=0.68$, $R^{2}=0.46, \mathrm{SEE}=2.02 \mathrm{~kg} ; \mathrm{ASM} 2, r=0.90, R^{2}=0.81$, SEE $=1.18 \mathrm{~kg} ; \mathrm{ASM} 3, r=0.90, R^{2}=0.81$, SEE $=1.17 \mathrm{~kg} ;$ and ASM4, $r=0$. $91, R^{2}=0.82$, SEE $=1.14 \mathrm{~kg}$. ASMM estimated by ASM3 was not significantly different $(P>0.05)$ from ASMMDXA with mean difference of -0.05 (range, 0.12 to -0.23 ). Bland and Altman plot revealed satisfactory measurement agreements between ASM3 and ASMM DXA. The ASMM estimated by the other three models was significantly different from the $\operatorname{ASMM}_{D X A}(P<0.05)$.

Conclusion: The ASM3 model introduced by Wen et al. met all validation criteria and can be recommended for the estimation of ASMM in middle-aged women in Sri Lanka.
\end{abstract}

Keywords: Anthropometry models, Appendicular skeletal muscle mass, DXA, Women

\footnotetext{
* Correspondence: nirmala.priyanthi@gmail.com

'Department of Nursing, Faculty of Allied Health Sciences, University of

Ruhuna, Galle, Sri Lanka

Full list of author information is available at the end of the article
}

(c) The Author(s). 2018 Open Access This article is distributed under the terms of the Creative Commons Attribution 4.0 International License (http://creativecommons.org/licenses/by/4.0/), which permits unrestricted use, distribution, and reproduction in any medium, provided you give appropriate credit to the original author(s) and the source, provide a link to the Creative Commons license, and indicate if changes were made. The Creative Commons Public Domain Dedication waiver (http://creativecommons.org/publicdomain/zero/1.0/) applies to the data made available in this article, unless otherwise stated. 


\section{Background}

Skeletal muscle mass (SMM) is a key component of body composition, accounting for $30-40 \%$ of total body weight $[1,2]$. It correlates with physical functions and health status [3] and involves in many processes related to health such as physiology, nutrition, clinical medicine [4], treatments, disease prevention, and long-term rehabilitation. Approximately 75\% of SMM is located in the appendicular region [5] called appendicular skeletal muscle mass (ASMM), and reduction of ASMM leads to negative health consequences such as weakness, disability, impaired quality of life (QOL), and mortality resulting in increased health care burden $[6,7]$.

SMM is quantifiable using many techniques. Although standard techniques like MRI, CT, and dual-energy $\mathrm{x}$-ray absorptiometry (DXA) are used to measure the SMM with high accuracy, they are expensive and not widely accessible and some have high radiation exposure. As an alternative, the indices of anthropometry, often in combination, are used to estimate or to predict SMM and the distinct advantages of anthropometry-based techniques are that they are noninvasive and inexpensive and can be applied in a wide range of clinical and research settings [8].

Martin et al. [9], in 1989, formulated a prediction model for SMM based on anthropometry with high precision $\left(R^{2}=0.93\right)$, and this model was further modified to make it more accurate and user friendly $\left(R^{2}=0.96\right)$ [10]. Later, similar studies had been carried out mostly in western communities [4, 11-14] and only a few have been reported from Asia [15, 16]. Of these studies, models introduced by Lee et al. [12] and Wen et al. [16] are applicable across a wide range of age while other models [4, 11, 13, 14] are more applicable for elderly population.

Lee et al. [12] introduced two formulae to estimate the ASMM in adults in the Western population comprising different ethnicities. They are based on anthropometric measures such as weight, height, circumferences, and skinfold thicknesses (SFTs) of selected sites, in combination with general information such as age, gender, and ethnicity. Wen et al. [16] too have adopted a similar approach for the Chinese population. Both models have been validated against the ASMM measured by MRI [12] and DXA [16] as the criterion method.

In Sri Lanka, the use of anthropometry in clinical decision-making is mostly limited to height, weight, and BMI with occasional use of abdominal girth. These are used as crude estimates of regional and global adiposity or when following guidelines based on these measures. Muscle mass, although shown to be a determinant of clinical outcome in many diseases, is hardly used in clinical decision-making in Sri Lanka due to lack of advanced technology to measure muscle mass and lack of guidelines for clinical applications.
It is pertinent to find methods that are inexpensive yet accurate and applicable in clinical settings to estimate ASMM for the use of clinicians and researchers. This would encourage research related to this area and subsequently in the development of guidelines for the use of muscle mass in clinical decision-making. The current study aimed at assessing the validity of selected mathematical models to estimate ASMM among middle-aged women. In order to allow for possible geographical variations in the predictors of muscle mass, we used four models, two validated among Western subjects and the other two validated in a group of Chinese subjects.

\section{Methods}

\section{Study design, setting, and participants}

This cross-sectional study was conducted in a group of 165 healthy community-dwelling women, aged 30-60 years randomly selected from permanent residents in the Galle District, Sri Lanka, during the period July 2015-July 2016.

Women who used medications that were likely to have an effect on muscle mass (thyroxin, corticosteroids, hormone replacement therapy (HRT), and oral contraceptives), who were on dedicated dietary or exercise programs, and with non-communicable diseases (NCD), polycystic ovarian syndrome (PCOS), and chronic pulmonary, cardiac, hepatic, or renal diseases, were excluded. Furthermore, women with limb deformities and disorders of nervous and musculoskeletal systems were also excluded from the study.

\section{Measured variables}

The following anthropometric variables were measured in all subjects adhering to standard protocols [17]. Body weight was measured to the nearest $0.1 \mathrm{~kg}$ using a digital weighing scale (NAGATA, Tainan, Taiwan) while the subjects were wearing light clothes. The weighing scale is calibrated annually with daily spot check according to the manufacturer's guidelines. Standing height was measured without footwear and recorded to the nearest $0.1 \mathrm{~cm}$ with a stadiometer (NAGATA, Tainan, Taiwan). Circumferences at three sites, right mid-upper arm, right mid-thigh, and right medial calf, were obtained in triplicate to the nearest $0.1 \mathrm{~cm}$ while subjects were standing erect. SFTs were measured in triplicate over the triceps, calf, and thigh on the right side using a skinfold caliper (Holtan Ltd., UK) to the nearest $1.0 \mathrm{~mm}$. Measurement consistency between the consecutive measurements was considered as $1.0 \mathrm{~mm}$, and if not, another separate measurement was taken. Three measurements that were within the acceptable range were then averaged. Details of the sites measured are given in Table 1. All the measurements were obtained by a single trained investigator to ensure the consistency of the measurements. The limb circumferences $\left(C_{\text {limb }}\right)$ were corrected for 
Table 1 SFT and circumference measurement sites

\begin{tabular}{lll}
\hline Site & SFT measurement & Circumference measurement \\
\hline Upper arm & $\begin{array}{l}\text { Triceps-measured in the midline posteriorly over the triceps } \\
\text { muscle at a point midway between the lateral projection of } \\
\text { the acromion process of the scapula and the inferior margin } \\
\text { of the olecranon process of the ulna. }\end{array}$ & $\begin{array}{l}\text { Measured midway between the lateral projection of the acromion } \\
\text { process of the scapula and the inferior margin of the olecranon } \\
\text { process of the ulna }\end{array}$ \\
Thigh & $\begin{array}{l}\text { Measured at the midline of the anterior aspect of the thigh, } \\
\text { midway between the inguinal crease and the proximal } \\
\text { boarder of the patella }\end{array}$ & $\begin{array}{l}\text { Measured midway between the midpoint of the inguinal crease } \\
\text { and the proximal border of the patella }\end{array}$ \\
Calf & $\begin{array}{l}\text { Measured on the medial aspect of the calf at the same level } \\
\text { as the calf circumference }\end{array}$ & Measured at the maximal circumference
\end{tabular}

subcutaneous adipose tissue thickness [9, 10]. The corrected muscle (including the bone) circumferences $\left(C_{\mathrm{m}}\right)$ were calculated as $C_{\mathrm{m}}=C_{\text {limb }}-\pi S(S, \mathrm{SFT}) . C_{\mathrm{m}}$ was considered as corrected girth (CAG-corrected arm girth, CTG-corrected thigh girth, CCG-corrected calf girth). In addition, as appendicular circumferences are uni-dimensional and muscle mass is three-dimensional, $C_{\mathrm{m}}$ was squared and multiplied by height to convert to a three-dimensional measure $[9,10]$.

ASMM measured by DXA (ASMM ${ }_{\text {DXA }}$ ) (Hologic Discovery W, Hologic Inc., Bedford, MA, USA) was used as the reference standard in this study. Subjects were scanned in light, metal-free clothing while lying flat on the table. The same technician who calibrated the machine daily performed all scans and analyzed them according to the manufacturer's guidelines to avoid inter-operator variability. ASMM $M_{\text {DXA }}$ was determined by the sum of SMM of lower and upper limbs [4]. Body fat percentage (\%) was also measured with DXA.

\section{Anthropometric models validated in the study}

The models considered in this study are explained in Table 2. The two models developed by Lee et al. [12] (ASM1, ASM2) and the two models developed by Wen et al. [16] (ASM3, ASM4) were considered for cross validation. The models ASM1 and ASM3 are based on circumferences and SFTs while the models ASM2 and
ASM4 are based on body weight and height. Gender, age, and ethnicity are independent inputs in all four models. Table 2 presents information related to the original validation of the four models selected for this study.

\section{Statistical analysis}

Data were analyzed using SPSS 20.0 (IBM statistics, Inc., Chicago). Descriptive statistics means (SD) or frequencies (\%) were used to describe the data. Pearson correlation coefficients, unadjusted and then adjusted for age and menopausal status, were used to identify the associations between anthropometric variables and $\mathrm{ASMM}_{\mathrm{DXA}}$. $P$ value $<0.05$ was considered statistically significant.

Pearson correlation coefficient $(r)$ was used to determine the correlation between ASMM predicted by existing

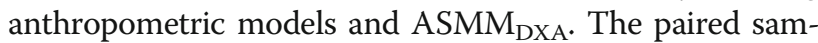
ple $t$ test was applied to verify the differences between $\mathrm{ASMM}_{\mathrm{DXA}}$ and ASMM predicted by models. Additionally, $R^{2}$ and SEE were determined with regression analysis. The models were considered valid when there was no significant difference between the mean values, SEE was < $3.5 \mathrm{~kg}$, and $R^{2}$ was $>0.7$ as recommended by Lohman [18] and later followed by Pereira et al. [13]. The models which fulfilled all three cross-validation criteria were further tested for repeatability with Bland and Altman plots [19].

Table 2 Models tested with the validation criteria and methods used by the authors

\begin{tabular}{|c|c|c|c|c|c|}
\hline $\begin{array}{l}\text { Models } \\
\text { developed by }\end{array}$ & $\begin{array}{l}\text { Criterion method } \\
\text { used by authors }\end{array}$ & $\begin{array}{l}\text { Models } \\
\text { specification }\end{array}$ & Model & $R^{2}$ & SEE \\
\hline \multirow[t]{2}{*}{$\begin{array}{l}\text { Lee et al. } \\
(2000)\end{array}$} & MRI & $\begin{array}{l}\text { Circumference-skin } \\
\text { fold model }\end{array}$ & $\begin{array}{l}\text { ASM } 1=\text { height }\left(0.00744 \times C \mathrm{CA}^{2}+0.00088 \times \mathrm{CTG}^{2}+0.00441 \times \mathrm{CCG}^{2}\right)+2.4 \times \\
\text { sex }-0.048 \times \text { age }+ \text { race }+7.8(\text { where sex: females }=0, \text { males }=1 \text { and race: } \\
\text { Asian }=-2, \text { African American }=1.1, \text { Hispanics }=0)\end{array}$ & 0.91 & 2.2 \\
\hline & & Weight-height model & $\begin{array}{l}\text { ASM } 2=0.244 \times \text { weight }+7.80 \times \text { height }+6.6 \times \text { sex }-0.098 \times \text { age }+ \text { race }-3.3 \\
(\text { where sex: female }=0, \text { male }=1 \text { and race: Asian }=-1.2 \text {, African American } \\
=1.4, \text { Hispanic }=0)\end{array}$ & 0.86 & 2.8 \\
\hline \multirow[t]{2}{*}{$\begin{array}{l}\text { Wen et al. } \\
(2011)\end{array}$} & DXA & $\begin{array}{l}\text { Circumference-skin } \\
\text { fold model }\end{array}$ & $\begin{array}{l}\text { ASM } 3=\text { height }\left(0.001509 \times \mathrm{CAG}^{2}+0.000855 \times \mathrm{CTG}^{2}+0.0007709 \times \mathrm{CCG}^{2}\right) \\
-4.044 \times \text { sex } 0.149 \times \text { weight }-0.038 \times \text { age }+12.246(\text { where sex: female }=2 \\
\text { male }=1)\end{array}$ & 0.92 & 1.44 \\
\hline & & $\begin{array}{l}\text { Weight-height } \\
\text { model }\end{array}$ & $\begin{array}{l}\text { ASM } 4=0.193 \times \text { weight }+0.107 \times \text { height }-4.175 \times \text { gender }-0.037 \times \text { age }-2.631 \\
(\text { where sex: female }=2, \text { male }=1)\end{array}$ & 0.90 & 1.63 \\
\hline
\end{tabular}




\section{Ethical considerations}

Ethical clearance for the study was obtained from the Ethical Review Committee, Faculty of Medicine, University of Ruhuna, Sri Lanka, and informed written consent was obtained from each participant prior to the commencement of the study.

\section{Results}

The basic characteristics and anthropometric indices of study participants are shown in Table 3. Mean (SD) ASMM $_{\text {DXA }}$ was $15.39(2.75) \mathrm{kg}$. All anthropometric indices studied showed positive correlations with ASMM $_{\text {DXA }}$ (Table 3). The results did not change materially when the correlations were adjusted for age and menopausal status.

Studied women had wider BMI (mean \pm SD, $25.36 \pm$ 4.32; range, $15.91-36.94 \mathrm{~kg} / \mathrm{m}^{2}$ ) and body fat percentage (mean $\pm \mathrm{SD}, 36.21 \pm 5.53$; range, $20.20-52.10 \%$ ) ranges (Table 3). The correlations between body fat percentage and SFT of the triceps, thigh, and calf were $r=0.60, r=$ 0.60 , and $r=0.55$, respectively, and the correlations between body fat percentage and circumferences of the upper arm, thigh, and calf were $r=0.55, r=0.39$, and $r=0.34$, respectively (data not shown in Tables).
Table 4 shows the results of cross validation of four tested models: ASMM estimated by these models showed strong correlations ranged between 0.68 and 0.82. ASMM estimated by ASM1 showed lesser $R^{2}(46 \%)$ compared to the ASMM estimated by the other three models. $\mathrm{ASMM}_{\mathrm{DXA}}$ and ASMM estimated with ASM3 were not significantly different (mean difference, 0.05 ; range of difference, -0.23 to $0.12 ; P=0.57$ ); and ASMMs estimated by the other three models were significantly different from $\mathrm{ASMM}_{\mathrm{DXA}}$ (Table 4).

When the measurement agreement of the $\mathrm{ASMM}_{\mathrm{DXA}}$ and ASMM estimated by ASM3 was tested by the Bland and Altman plot, more than $95 \%$ of values were within the limits of agreement $( \pm 1.96 \mathrm{SD}$ of the mean difference, -2.24 to 2.34) indicating the accuracy of the ASM3 model (Fig. 1).

\section{Discussion}

In this study, $\mathrm{ASMM}_{\mathrm{DXA}}$ showed varying but strong correlations with ASMMs estimated by all selected models. ASM1 showed the highest measurement error while the other three models showed very similar results. ASM3, the circumference-skinfold model developed by Wen et al.

Table 3 Physical characteristics of the study participants and correlation of anthropometric indices with $\mathrm{ASMM}_{\mathrm{DXA}}(n=165)$

\begin{tabular}{|c|c|c|c|c|c|}
\hline \multirow{2}{*}{$\begin{array}{l}\text { Characteristics/ } \\
\text { parameter }\end{array}$} & \multirow[t]{2}{*}{ Mean (SD) } & \multicolumn{4}{|c|}{ Correlation with $\mathrm{ASMM}_{\mathrm{DXA}}$} \\
\hline & & $\begin{array}{l}\text { Pearson } \\
\text { correlation** }\end{array}$ & $\begin{array}{l}\text { Age-adjusted partial } \\
\text { correlation** }\end{array}$ & $\begin{array}{l}\text { Menopausal status-adjusted } \\
\text { partial correlation** }\end{array}$ & $\begin{array}{l}\text { Age and menopausal-adjusted } \\
\text { partial correlation** }\end{array}$ \\
\hline Age (years) & $49.1(8.2)$ & - & - & - & - \\
\hline Height (m) & $1.50(0.06)$ & 0.55 & 0.53 & 0.53 & 0.53 \\
\hline Weight (kg) & $57.52(10.62)$ & 0.87 & 0.88 & 0.89 & 0.89 \\
\hline BMI $\left(\mathrm{kg} / \mathrm{m}^{2}\right)$ & $25.36(4.32)$ & 0.67 & 0.70 & 0.70 & 0.71 \\
\hline SFT at triceps (mm) & $19.47(6.09)$ & 0.53 & 0.51 & 0.52 & 0.51 \\
\hline SFT at thigh (mm) & $27.71(9.90)$ & 0.38 & 0.36 & 0.37 & 0.36 \\
\hline SFT at calf (mm) & $18.63(8.41)$ & 0.43 & 0.41 & 0.41 & 0.41 \\
\hline $\begin{array}{l}\text { Upper arm } \\
\text { circumference }(\mathrm{cm})\end{array}$ & $31.15(3.85)$ & 0.73 & 0.74 & 0.75 & 0.75 \\
\hline $\begin{array}{l}\text { Thigh } \\
\text { circumference }(\mathrm{cm})\end{array}$ & $49.07(7.41)$ & 0.56 & 0.56 & 0.56 & 0.56 \\
\hline $\begin{array}{l}\text { Calf } \\
\text { circumference }(\mathrm{cm})\end{array}$ & $34.40(5.68)$ & 0.52 & 0.51 & 0.51 & 0.50 \\
\hline CAG & $25.03(2.84)$ & 0.60 & 0.63 & 0.62 & 0.63 \\
\hline CTG & $40.35(6.78)$ & 0.47 & 0.47 & 0.46 & 0.47 \\
\hline CCG & $28.54(4.93)$ & 0.25 & 0.22 & 0.23 & 0.22 \\
\hline $\mathrm{CAG}^{2}$ height & $957.39(229.21)$ & 0.68 & 0.69 & 0.69 & 0.70 \\
\hline $\mathrm{CTG}^{2}$ height & $2525.41(758.69)$ & 0.59 & 0.59 & 0.59 & 0.59 \\
\hline $\mathrm{CCG}^{2}$ height & $1264.75(513.97)$ & 0.25 & 0.23 & 0.23 & 0.23 \\
\hline $\mathrm{ASMM}_{\mathrm{DXA}}$ & $15.39(2.75)$ & - & - & - & - \\
\hline $\begin{array}{l}\text { Body fat } \\
\text { percentage (\%) }\end{array}$ & $36.21(5.53)$ & - & - & - & - \\
\hline
\end{tabular}

BMI body mass index, SFT skin fold thickness, CAG corrected arm girth, CTG corrected thigh girth, CCG corrected calf girth, $A S M M_{D X A}$ DXA measured appendicular skeletal muscle mass

${ }^{* *}$ All the variables were significantly correlated at $<0.001$ level 
Table 4 Cross validation of ASMM estimated with models developed by Lee et al. and Wen et al. with ASMMDXA $(n=165)$

\begin{tabular}{|c|c|c|c|c|c|c|c|c|c|}
\hline \multirow[t]{2}{*}{ Models } & & \multicolumn{3}{|c|}{ Pearson correlation and regression analysis } & \multirow{2}{*}{$\begin{array}{l}\text { Mean (SD) } \\
(\mathrm{kg})\end{array}$} & \multicolumn{4}{|c|}{ Paired sample $t$ test } \\
\hline & & $r$ & $R^{2}$ & SEE (kg) & & $\overline{\mathrm{MD} / \mathrm{SE}(\mathrm{kg})}$ & SD & Range of mean difference $(\mathrm{kg})$ & $P$ value \\
\hline \multirow[t]{2}{*}{ Lee et al. (2000) } & ASM1 & $0.68^{*}$ & 0.46 & 2.02 & $18.36(3.27)$ & -2.97 & 2.45 & -3.35 to 2.59 & $<0.001$ \\
\hline & ASM2 & $0.90^{*}$ & 0.81 & 1.18 & $16.46(3.01)$ & -1.07 & 1.28 & -1.27 to -0.87 & $<0.001$ \\
\hline \multirow[t]{2}{*}{ Wen et al. (2011) } & ASM3 & $0.90^{*}$ & 0.81 & 1.17 & $15.44(2.40)$ & -0.05 & 1.17 & -0.23 to 0.12 & 0.57 \\
\hline & ASM4 & $0.91^{*}$ & 0.82 & 1.14 & $14.44(2.45)$ & 0.94 & 1.14 & 0.76 to 1.11 & $<0.001$ \\
\hline
\end{tabular}

$A S M M_{D X A}$ ASMM measured with DXA, $r$ Pearson correlation, $R^{2}$ determination coefficient, SEE standard error of estimate, $M D$ mean difference, $S E$ standard error ${ }^{*}$ Correlations were significant at $<0.001$ level

[16], however, met all the validation criteria published by Lohman [18] and emerged as the best prediction model for this group of women.

Our data are consistent with Wen et al. [16] who have shown that the circumference-skinfold model (ASM3) is better compared to the weight-height model (ASM4) even though ASM4 is more practical and easily adoptable in any setting.

ASM1 and ASM2 [12] that have been developed using data from multi-ethnic US population did not meet the validation criteria we followed. These models have used data from non-obese males and females in a broad age range of 18-80 years and MRI as the reference standard. The current study included only women in a narrow age range, ages between 30 and 60 years, in wider BMI and body fat percentage ranges, and these may have accounted for the discrepancy we observed. This inconsistency is further explained by the lower values of height-adjusted ASMM in our women compared to NHANSE reference standards, measured using Hologic DXA [20]. Furthermore, we used DXA as the reference standard in our analyses.
Wen et al. [16] have also used subjects in a broad age range (19-69 years). However, the inclusion and exclusion criteria were similar to the current study. Further, they used DXA as the reference standard. The comparability of study samples may explain the measurement agreement shown by these models.

In adopting a model developed elsewhere to a local population, the disparities of the two populations with regard to the genetics, nutrition, and physical activities may play a significant role in determining the adoptability of such a model. This may partly explain the accuracy of ASM3 which is based on Chinese data, when applied to Sri Lankan subjects.

Development of country-specific prediction models is a daunting task, and many have attempted adopting models developed elsewhere to local population with varying success. Rech et al. [21] found a high agreement between measured and estimated ASMM in Brazil. A similar attempt has been made by Lekamwasam and Nanayakkara [22] who validated a weight- and height-based model in a group of Sri Lankan women.

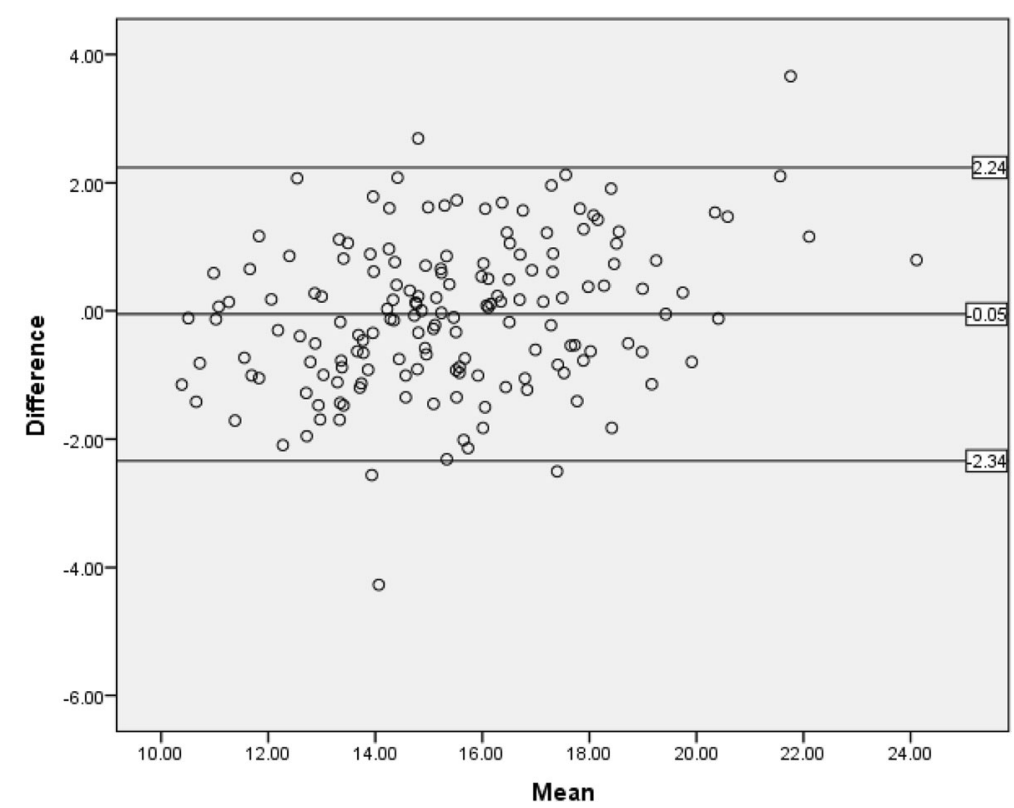

Fig. 1 Agreement between ASM3 developed by Wen et al and the reference standard of ASMM (ASMM $\left.M_{D X A}\right)(n=165)$ 
In contrast to the previous study done in Sri Lanka, we found the model which included circumference and SFT (ASM3) to have better accuracy in estimating ASMM. We believe that circumference and SFT add new dimensions to the prediction model to improve its output. SFT is basically a measurement of fat mass, and circumference usually measures both SMM and fat mass. We observed that the relationships between body fat percentage and SFT of the triceps, thigh, and calf were stronger than the relationships observed between ASMM and SFTs. In contrast, the relationships between body fat percentage and circumferences of the upper arm, thigh, and calf were weaker than the relationships observed between ASMM and circumference. However, both menopause- and age-related changes in fat deposition and loss of skin elasticity contribute to variations in both measurements [23] and such adjustments used in these studies may overcome the errors in estimation of muscle mass.

In our analysis, the ASM3 is the best model to predict muscle mass and it would explain $81 \%\left(R^{2}=0.81\right)$ of the muscle mass variation. One may consider adding other anthropometry measures such as bicep SFT and arm length to improve the predictability of these models. Further, utilization of site-specific anthropometry indices would provide more accurate prediction of muscle mass of specific regions. Therefore, upper arm circumference for the upper limb muscle mass and thigh circumference for the lower limb muscle mass [24] would be more appropriate than the current approach. However, the lack of facilities restricts the applicability of such an advanced method in the current study.

The current study has a few limitations. It involved only a sample of relatively healthy females aged 3060 years selected from a single area of the country. This may limit the generalizability of the models, particularly in clinical situations. Prospective large-scale validation studies are required to determine the validity of these prediction models among different age groups and in different clinical situations.

\section{Conclusions}

This study proved the ability of anthropometry-based models to estimate ASMM accurately in middle-aged women in our setting. Except the weight-height-based model by Lee et al., the other three models showed a high measurement concordance. Circumference skinfold-based model (ASM3) by Wen et al., however, satisfied all the criteria we followed and emerged as the most accurate model to estimate the ASMM in middle-aged Sri Lankan women.

\section{Abbreviations}

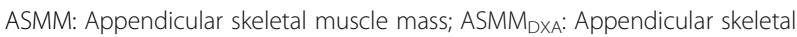
muscle mass measured by DXA; BMI: Body mass index; CAG: Corrected arm girth; CCG: Corrected calf girth; CT: Computer tomography; CTG: Corrected thigh girth; DXA: Dual energy x-ray absorptiometry; HRT: Hormone replacement therapy; MRI: Magnetic resonance imaging; NCD: None communicable diseases; PCOS: Polycystic ovarian syndrome; QOL: Quality of life; SD: Standard deviation; SEE: Standard error of estimate; SFT: Skinfold thickness; SPSS: Statistical package for social sciences; UK: United Kingdom; US: United States; USA: United States of America

\section{Acknowledgements}

The authors wish to express sincere gratitude to Ms. Malini Kariyawasam and Ms. Rajika Niroshini of DXA unit, Teaching Hospital, Karapitiya.

\section{Funding}

The Faculty Research Grant (2014-2015), Faculty of Medicine, University of Ruhuna, Sri Lanka, and the National Research Council (NRC 15-023), Sri Lanka, funds mainly involved with the collection of data.

\section{Availability of data and materials}

The datasets used and/or analyzed during the current study are available from the corresponding author on reasonable request.

\section{Authors' contributions}

All authors involved in the conception of the study and design of the work. NR involved in the data collection, data analysis, and initial drafting of the manuscript. GA and $J L$ involved in the interpretation of the analyzed data and critically reviewed the manuscript. SL contributed to the interpretation of the analyzed data and critically reviewed the manuscript for important intellectual content. All authors read and approved the final version of the manuscript to be published.

\section{Ethics approval and consent to participate}

Ethical clearance for the study was obtained from the Ethical Review Committee, Faculty of Medicine, University of Ruhuna, Sri Lanka. Informed written consent was obtained from each participant prior to the commencement of the study.

\section{Consent for publication}

Not applicable

\section{Competing interests}

The authors declare that they have no competing interests.

\section{Publisher's Note}

Springer Nature remains neutral with regard to jurisdictional claims in published maps and institutional affiliations.

\section{Author details}

${ }^{1}$ Department of Nursing, Faculty of Allied Health Sciences, University of Ruhuna, Galle, Sri Lanka. 'Department of Anatomy, Faculty of Medicine, University of Ruhuna, Galle, Sri Lanka. ${ }^{3}$ Department of Physiology, Faculty of Medicine, University of Ruhuna, Galle, Sri Lanka. ${ }^{4}$ Department of Medicine, Faculty of Medicine, University of Ruhuna, Galle, Sri Lanka.

Received: 3 October 2017 Accepted: 16 July 2018

Published online: 31 July 2018

\section{References}

1. Maltais ML, Desroches J, Dionne IJ. Changes in muscle mass and strength after menopause. J Musculoskelet Neuronal Interact. 2009;9(4):186-97. https://www.ncbi.n/m.nih.gov/pubmed/19949277. Accessed 18 Sept 2017.

2. Goodpaster BH, Park SW, Harris TB, Kritchevsky SB, Nevitt M, Schwartz AV, Simonsick EM, Tylavsky FA, Visser M, Newman AB. The loss of skeletal muscle strength, mass, and quality in older adults: the health, aging and body composition study. J Gerontol A Biol Sci Med Sci. 2006;61(10):1059-64. https://www.ncbi.nlm.nih.gov/pubmed/17077199. Accessed 18 Sept 2017.

3. Delmonico MJ, Harris TB, Lee JS, Visser M, Nevitt M, Kritchevsky SB, Tylavsky FA, Newman AB, Health A, Body Composition S. Alternative definitions of sarcopenia, lower extremity performance, and functional impairment with aging in older men and women. J Am Geriatr Soc. 2007:55(5):769-74. https://www.ncbi.nlm.nih.gov/pubmed/17493199. Accessed 18 Sept 2017.

4. Baumgartner RN, Koehler KM, Gallagher D, Romero L, Heymsfield SB, Ross RR, Garry PJ, Lindeman RD. Epidemiology of sarcopenia among the elderly 
in New Mexico. Am J Epidemiol. 1998;147(8):755-63. https:/www.ncbi.nlm. nih.gov/pubmed/9554417. Accessed 18 Sept 2017.

5. Gallagher D, Visser M, De Meersman RE, Sepulveda D, Baumgartner RN, Pierson RN, Harris T, Heymsfield SB. Appendicular skeletal muscle mass: effects of age, gender, and ethnicity. J Appl Physiol (1985). 1997;83(1):22939. https://www.ncbi.nlm.nih.gov/pubmed/9216968. Accessed 18 Sept 2017.

6. Janssen I, Heymsfield SB, Ross R. Low relative skeletal muscle mass (sarcopenia) in older persons is associated with functional impairment and physical disability. J Am Geriatr Soc. 2002;50(5):889-96. https://www.ncbi. nlm.nih.gov/pubmed/12028177. Accessed 18 Sept 2017.

7. Cruz-Jentoft AJ, Baeyens JP, Bauer JM, Boirie Y, Cederholm T, Landi F, Martin FC, Michel JP, Rolland Y, Schneider SM, et al. Sarcopenia: European consensus on definition and diagnosis: report of the European Working Group on Sarcopenia in Older People. Age Ageing. 2010;39(4):412-23. https://www.ncbi.nlm.nih.gov/pubmed/20392703. Accessed 18 Sept 2017.

8. Wang J, Thornton JC, Kolesnik S, Pierson RN Jr. Anthropometry in body composition: an overview. Ann N Y Acad Sci. 2000;904:317-26. https://www. ncbi.nlm.nih.gov/pubmed/10865763. Accessed 18 Sept 2017.

9. Martin AD, Spenst LF, Drinkwater DT, Clarys JP. Anthropometric estimation of muscle mass in men. Med Sci Sports Exerc. 1990;22(5):729-33. https:// www.ncbi.nlm.nih.gov/pubmed/2233214. Accessed 18 Sept 2017.

10. Doupe MB, Martin AD, Searle MS, Kriellaars DJ, Giesbrecht GG. A new formula for population-based estimation of whole body muscle mass in males. Can J Appl Physiol. 1997;22(6):598-608. https://www.ncbi.nlm.nih. gov/pubmed/9415832. Accessed 18 Sept 2017.

11. Tanko LB, Movsesyan L, Mouritzen U, Christiansen C, Svendsen OL. Appendicular lean tissue mass and the prevalence of sarcopenia among healthy women. Metabolism. 2002;51(1):69-74. https://www.ncbi.nlm.nih. gov/pubmed/11782875. Accessed 18 Sept 2017.

12. Lee RC, Wang Z, Heo M, Ross R, Janssen I, Heymsfield SB. Total-body skeletal muscle mass: development and cross-validation of anthropometric prediction models. Am J Clin Nutr. 2000;72(3):796-803. https://www.ncbi. nlm.nih.gov/pubmed/10966902. Accessed 18 Sept 2017.

13. Pereira PM, da Silva GA, Santos GM, Petroski EL, Geraldes AA. Development and validation of anthropometric equations to estimate appendicular muscle mass in elderly women. Nutr J. 2013;12:92. https://www.ncbi.nlm.nih. gov/pubmed/23815948. Accessed 18 Sept 2017.

14. Abe T, Thiebaud RS, Loenneke JP, Young KC. Prediction and validation of DXA-derived appendicular lean soft tissue mass by ultrasound in older adults. Age (Dordr). 2015;37(6):114. https://www.ncbi.nlm.nih.gov/pubmed/ 26552906. Accessed 18 Sept 2017.

15. Kuriyan R, Thomas T, Kurpad AV. Total body muscle mass estimation from bioelectrical impedance analysis \& simple anthropometric measurements in Indian men. Indian J Med Res. 2008;127(5):441-6. https://www.ncbi.nlm.nih. gov/pubmed/18653906. Accessed 18 Sept 2017.

16. Wen $X$, Wang M, Jiang CM, Zhang YM. Anthropometric equation for estimation of appendicular skeletal muscle mass in Chinese adults. Asia Pac J Clin Nutr. 2011;20(4):551-6. https://www.ncbi.nlm.nih.gov/pubmed/ 22094840. Accessed 18 Sept 2017.

17. Lohman TG, Roche AF, Martorell R. Anthropometric standardization reference manual. Human kinetics books; 1988.

18. Lohman TG. Advances in body composition assessment. Human Kinetics Publishers; 1992

19. Bland JM, Altman D. Statistical methods for assessing agreement between two methods of clinical measurement. Lancet. 1986;327(8476):307-10. https://www.ncbi.nlm.nih.gov/pubmed/2868172. Accessed 18 Sept 2017.

20. Kelly TL, Wilson KE, Heymsfield SB. Dual energy $X$-ray absorptiometry body composition reference values from NHANES. PloS one. 2009;4(9):e7038. http://journals.plos.org/plosone/article?id=10.1371/journal.pone.0007038. Accessed 25 Mar 2018.

21. Rech CR, Dellagrana RA, MdFN M, Petroski EL. Validity of anthropometric equations for the estimation of muscle mass in the elderly. Revista Brasileira de Cineantropometria \& Desempenho Humano. 2012;14(1):23-31. http:// www.scielo.br/scielo.php?pid=\$1980-00372012000100003\&script=sci_ abstract. Accessed 18 Sept 2017.

22. Lekamwasam S, Nanayakkara J. Concordance between measured and estimated appendicular muscle mass in adult females. Ceylon Med J. 2015;60(3):100-2. https://www.ncbi.nlm.nih.gov/pubmed/26520864. Accessed 18 Sept 2017.

23. Rolland Y, Lauwers-Cances V, Cournot M, Nourhashemi F, Reynish W Riviere D, Vellas B, Grandjean H. Sarcopenia, calf circumference, and physical function of elderly women: a cross-sectional study. J Am Geriatr Soc. 2003;51(8):1120-4. https://www.ncbi.n/m.nih.gov/pubmed/12890076. Accessed 18 Sept 2017.

24. Diano D, Ponti F, Guerri S, Mercatelli D, Amadori M, Gómez MPA, Battista G, Guglielmi G, Bazzocchi A. Upper and lower limbs composition: a comparison between anthropometry and dual-energy $\mathrm{X}$-ray absorptiometry in healthy people. Arch Osteoporos. 2017;12(1):78. https://www.ncbi.nlm.nih. gov/pubmed/28921453. Accessed 25 Mar 2018.

\section{Ready to submit your research? Choose BMC and benefit from:}

- fast, convenient online submission

- thorough peer review by experienced researchers in your field

- rapid publication on acceptance

- support for research data, including large and complex data types

- gold Open Access which fosters wider collaboration and increased citations

- maximum visibility for your research: over $100 \mathrm{M}$ website views per year

At BMC, research is always in progress.

Learn more biomedcentral.com/submissions 